\title{
GROWTH OF EUROPIUM-DOPED MAGNESIUM SELENIDE FILMS BY ELECTRIC FIELD-ASSISTED SPRAY PYROLYSIS: OPTICAL AND STRUCTURAL ANALYSIS
}

\author{
(DD.M. Jeroh*, (D)A.J. Ekpunobi, (DD.N. Okoli \\ Physics/Industrial Physics Department, Nnamdi Azikiwe University, Nigeria \\ *E-mail: jeruaye@gmail.com \\ Received 25 October 2018, accepted 6 December 2018
}

Europium-doped MgSe films were deposited via electric field-assisted spray pyrolysis. The dopant concentration of the bulk solution of europium trioxide was $5 \mathrm{wt}$. \%. However, for doping the films at different substrate temperatures, volume percentage (vol. \%) was employed at each instance of variation. Variation of spray temperature was around $573 \mathrm{~K}$ and $673 \mathrm{~K}( \pm 0.3)$. Deposition occurred at optimized conditions. Spectra of absorption indicate poor absorption characteristics demonstrated by Europium-doped MgSe films in the ultra-violet region and very low absorption characteristics in the visible section. Absorption peaks were evident around 230nm, $240 \mathrm{~nm}, 350 \mathrm{~nm}$ and $365 \mathrm{~nm}$ which confirmed defect states are inherent inside the crystal structure of the films. The films displayed high transparency and low reflection in the visible section at varying substrate temperatures. The high transparency revealed by the $\mathrm{MgSe}: \mathrm{Eu}$ films in the visible section of the electromagnetic spectrum makes the material applicable as a coating layer in the manufacturing of transparent products. Band gap energies within the range of $2.49 \mathrm{eV}$ to $2.95 \mathrm{eV}$ corresponding to varying substrate temperatures $(573 \mathrm{~K}, 598 \mathrm{~K}, 623 \mathrm{~K}, 648 \mathrm{~K}$ and $673 \mathrm{~K})$ and film thicknesses $(2900 \mathrm{~nm}, 2750 \mathrm{~nm}, 2500 \mathrm{~nm}, 2100 \mathrm{~nm}$ and $200 \mathrm{~nm})$ were determined for the MgSe:Eu films. However, a clear observation shows that the band gaps of MgSe:Eu films are mainly dependent on thickness such that the obtained band gaps decreased with increasing thickness (band gap increases with thickness reduction). Structural analysis (XRD) studied at $10 \%$ and $40 \%$ Eu concentrations reveals a hexagonal (or wurzite) structure for the films with a distortion in crystallinity at higher dopant concentration (40 vol. \%) and a resultant blue shift in the lattice constant from the bulk value. Multiple planes of reflection from XRD pattern of the deposited $\mathrm{MgSe}: \mathrm{Eu}$ films indicate clearly that the films are polycrystalline. Surface morphology (SEM) confirms the highly strained nature and the presence of defect states within the crystal lattice of the Europium-doped MgSe films. Composition of MgSe:Eu films obtained by energy dispersive analysis X-ray (EDAX) confirms the growth of MgSe:Eu films.

KEYWORDS: Magnesium Selenide, Spray Pyrolysis, Europium, Temperature, Structural, Films, Band gap.

\section{РІСТ МАГНІЄВО-СЕЛЕНІДНИХ ПЛІВОК ЛЕГОВАНИХ СВРОПІЄМ МЕТОДОМ СПРЕЙ-ПІРОЛІЗУ В ЕЛЕКТРИЧНОМУ ПОЛІ: ОПТИЧНИЙ І СТРУКТУРНИЙ АНАЛІЗ \\ D.M. Jeroh, A.J. Ekpunobi, D.N. Okoli}

Physics/Industrial Physics Department, Nnamdi Azikiwe University, Nigeria

Плівки $\mathrm{MgSe}$ леговані європієм формувались за допомогою піролізу в електричному полі. Об'ємна концентрація домішки у розчині триоксиду європію становила $5 \mathrm{wt}$ \%. Проте при легуванні плівок при різних температурах субстрату, кожного разу використовувався об'ємний відсоток (vol. \%). Варіація температури напилення становила близько 573 К і 673 К ( $\pm 0,3$ ). Осадження відбувалося в оптимізованих умовах. Спектри абсорбції свідчать про слабкі поглинальні характеристики, продемонстровані плівками, що містять оксид $\mathrm{MgSe}$, в ультрафіолетовій області та дуже низькі характеристики поглинання у видимому діапазоні. Піки поглинання спостерігались навколо 230 нм, 240 нм, 350 нм та 365 нм, що підтверджує наявність дефектів всередині кристалічної структури плівок. Плівки демонстрували високу прозорість і низьку здатність до відбиття у видимому діапазоні при різних температурах підкладки. Висока прозорість, виявлена плівками $\mathrm{MgSe:Eu} \mathrm{у} \mathrm{видимому}$ діапазоні електромагнітного спектра, робить матеріал придатним у якості шару покриття для виготовлення прозорих виробів. Для плівок MgSe:Eu була визначена ширини енергетичної зони в межах від 2,49 до 2,95 еВ, що відповідала різним температурам підкладки (573 К, 598 К, 623 К, 648 К і 673 К) та товщин плівок (2900, 2750, 2500, 2100, 200 нм). Проте, спостереження чітко показує, що ширини енергетичної зони зразків плівок MgSe:Eu в основному залежать від товщини, так що отримані ширини енергетичної смуги зменшуються 3 збільшенням товщини (ширина смуги зростає із зменшенням товщини). Структурний аналіз (XRD), проведений для концентрацій $10 \%$ та $40 \%$ Eu, показує гексагональну (або вурцітну) структуру для плівок із порушенням кристалічності при більш високій концентрації домішки (40 об.\%) і як наслідок синій зсув константи решітки порівняно з об’ємним значенням. Кілька площин відбиття від шару XRD нанесених плівок MgSe:Еu чітко показують, що плівки є полікристалічними. Поверхнева морфологія (SEM) підтверджує високу напруженість та наявність дефектних станів у кристалічній решітці плівок $\mathrm{MgSe}$, що містять сплави Свропію. Структура плівок $\mathrm{MgSe}$ Еu, отриманих за допомогою енергетичного дисперсійного аналізу рентгенівського випромінювання (EDAX), підтверджує ріст плівок MgSe: $\mathrm{Eu}$.

КЛЮЧОВІ СЛОВА: селенід магнію, спрей-піроліз, європій, темпереатура, структура, плівки, ширина смуги

For decades, semiconductors have proven absolutely effective and reliable when it comes to designing and fabricating several electronic devices. Amongst the studied semiconductors, II-VI semiconductors have been widely reported in searching for novel materials toward advancing the study of semiconductors for various applications. As such, focus has shifted to the inclusion of magnetic and rare-earth ions into pure semiconductors to explore their variable properties. The alkaline earth chalcogenides such as $\mathrm{MgSe}, \mathrm{CaSe}, \mathrm{SrSe}$, etc., have attracted scientists perhaps due to their potential applications in various optoelectronic devices, especially luminescent ones [1]. Magnesium is located in group IIA and when combined with selenium, it can be classified as a II-VI semiconductor. Due to its 
hygroscopic nature and unstable zinc-blende structure, a detailed investigation on the physical properties of $\mathrm{MgSe}$ is not clear till now and only few reports are existent in the literature [2].

Magnesium selenide (MgSe) films have previously been produced by spray pyrolysis [1-4], solution growth technique [5-7], molecular beam epitaxy [8-9], metal-organic chemical vapour deposition [10], metal-organic vapourphase epitaxy [11]. In our current research, spray pyrolysis (SP) based on electrostatic field was used to deposit magnesium selenide with europium as dopant (MgSe:Eu) and a careful analysis of its optical and structural parameters are presented. SP was considered due to its advantages as reported by [12].

The major aim of this study is to introduce a pinch of europium (as a dopant) into MgSe and study its optical and structural characteristics for possible applications of the material. This became necessary as only few reports are available on the optical and structural parameters of $\mathrm{MgSe}$ films and also the inclusion of rare-earth ions (Europium) in magnesium selenide films has not been described in available literatures. This research aims to close the gap by investigating the optical and structural parameters of only Europium-doped magnesium selenide films and possibly suggest applications of the films based on their determined characteristics.

\section{EXPERIMENTAL DETAILS}

The spray content of $\mathrm{MgSe}: \mathrm{Eu}$ films comprises $1.8 \mathrm{ml}$ of $0.2 \mathrm{M}$ of magnesium acetate, $6 \mathrm{ml}$ of $0.2 \mathrm{M}$ of selenium dioxide $\left(\mathrm{SeO}_{2}\right)$ and $0.2 \mathrm{ml}$ of europium trioxide; $\mathrm{Eu}_{2} \mathrm{O}_{3}(0.1 \mathrm{M}$ concentration). $10 \%$ Dopant concentration (Vol. \%) was considered for temperature variation. The resulting mixture was whisked for 25 minutes by a magnetic stirrer. Due to swift precipitation of the mixture, the spray content was stabilized with the addition of some proportions of hydrochloric acid (concentrated). This was done to reduce the reaction pace of the mixture. Once homogeneity of the mixture was attained, it was sprayed via a syringe pump by spray pyrolysis (electrostatic) on the hot glass substrates maintained at $573 \mathrm{~K}, 598 \mathrm{~K}, 623 \mathrm{~K}, 648 \mathrm{~K}$ and $673 \mathrm{~K}$ respectively. Distance optimization between the nozzle and substrate was achieved at $4.7 \mathrm{~mm}$, solution flow-rate was maintained at $2400 \mu \mathrm{L} / \mathrm{hr}$ while time of deposition was maintained at 10 minutes. The voltage throughout the whole deposition process was constant (optimized) at about $5.5 \mathrm{kV}$.

\section{RESULTS/DISCUSSIONS \\ Optical parameters}

The film thickness was obtained by surface profile analysis using a DekTak Veeco 150 Stylus Surface Profiler. The absorbance spectra for MgSe:Eu films obtained at varying deposition temperatures are displayed in Figure 1.

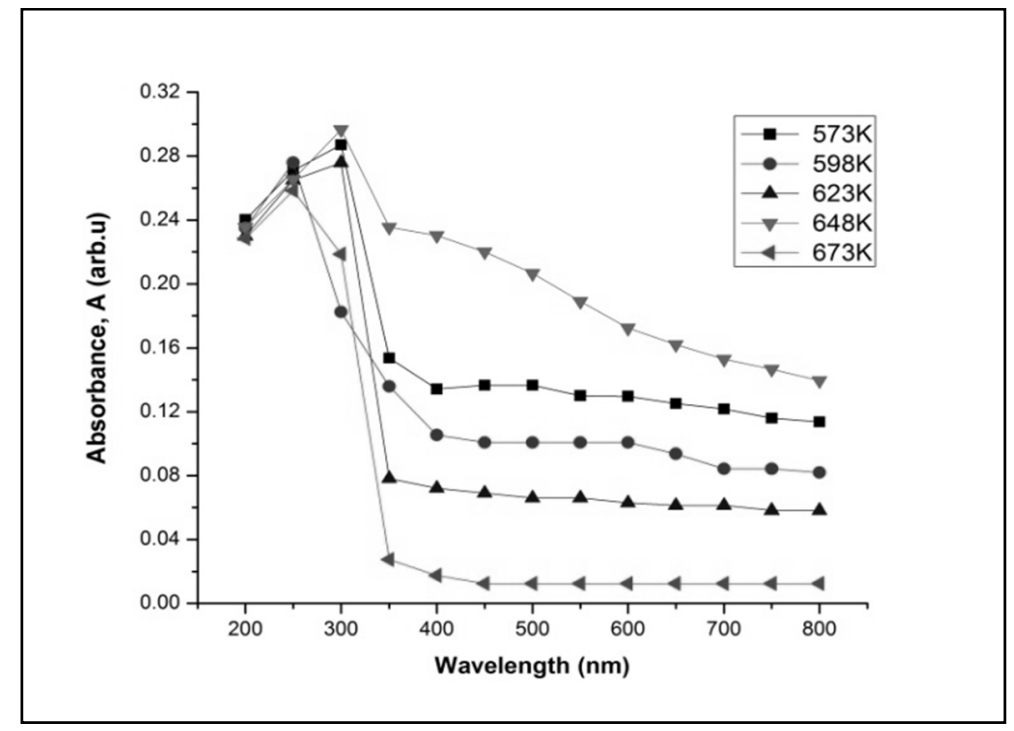

Fig. 1. Absorbance Spectra of MgSe:Eu Films at Varying Substrate Temperatures

Very poor absorption of light is obvious for the $\mathrm{MgSe}$ :Eu films at long wavelengths. Highest absorbance recorded is about $29.66 \%$ and was obtained at $648 \mathrm{~K}$ in the ultra-violet region. Absorption peaks are evident around $230 \mathrm{~nm}$, $240 \mathrm{~nm}, 350 \mathrm{~nm}$ and $365 \mathrm{~nm}$. These observed peaks confirm defect states are inherent inside the crystal structure of the films. The low absorption of light revealed by the MgSe:Eu films suggests that more light will be transmitted by the material. An observation of Figure 1 indicates that the absorbance of the MgSe:Eu films decreases as temperature increases from $573 \mathrm{~K}$ to $623 \mathrm{~K}$ in the visible region. At $643 \mathrm{~K}$, there was a sudden increase in absorbance with further decrease of absorption as deposition temperature attains $673 \mathrm{~K}$. This behaviour could be as a result of defect states or strains present within the material which is responsible for the slight distortion of trend. Notwithstanding, it could be concluded that absorption decreases with increment in temperature in the visible zone. From the SEM results (Figures $6 \mathrm{a}, \mathrm{b}$ ), cracks are observed on the surface of the films which is an indication that the films are highly strained 
and the confirmation of defect states within the crystal lattice. Thus the SEM and optical results are well correlated. The transmittance curves of MgSe:Eu films are displayed in Figure 2 for varying temperatures.

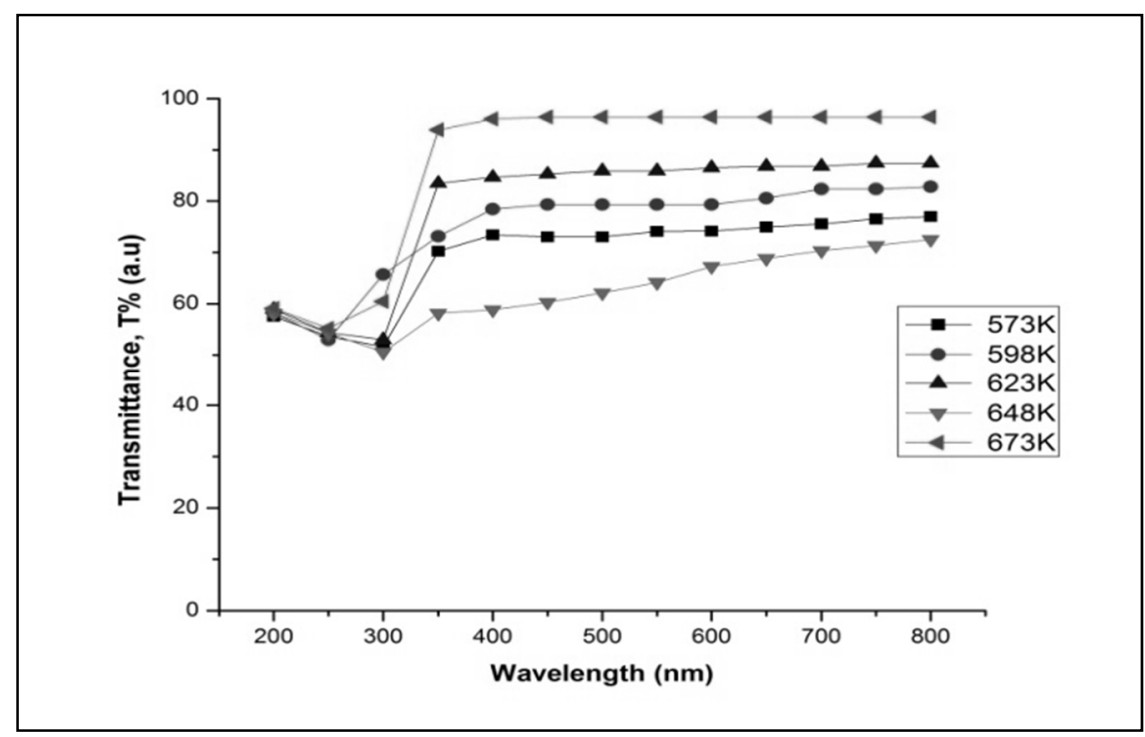

Fig. 2. Transmission Spectra for MgSe:Eu Films at Varying Substrate Temperatures

The transparency of the MgSe:Eu films improves with temperature from $573 \mathrm{~K}$ up to $623 \mathrm{~K}$, slightly decreased at $648 \mathrm{~K}$ and further increased at $673 \mathrm{~K}$. A careful inspection of all the films obtained at varying deposition conditions reveal high transparency around $73.42 \%$ and $96.47 \%$ in the visible region. The same reason adduced for the absorption results also applies to the transmittance results. This property of high transparency revealed by the $\mathrm{MgSe}: \mathrm{Eu}$ films in the visible section of the electromagnetic spectrum makes the material applicable as a coating layer in the manufacture of transparent products.

The band gap (direct) energies of the MgSe:Eu films at varying deposition conditions were computed from the relation [13]:

$$
(\alpha h v)=D\left(h v-E_{g}\right)^{m}
$$

where $\mathrm{D}$ is a constant, $\mathrm{m}$ indicates the transition type. The value of $\mathrm{m}$ is assigned either $1 / 2$ or 2 (for direct and indirect transitions respectively), Eg denotes energy of the band gap while hv stands for energy of the photon.

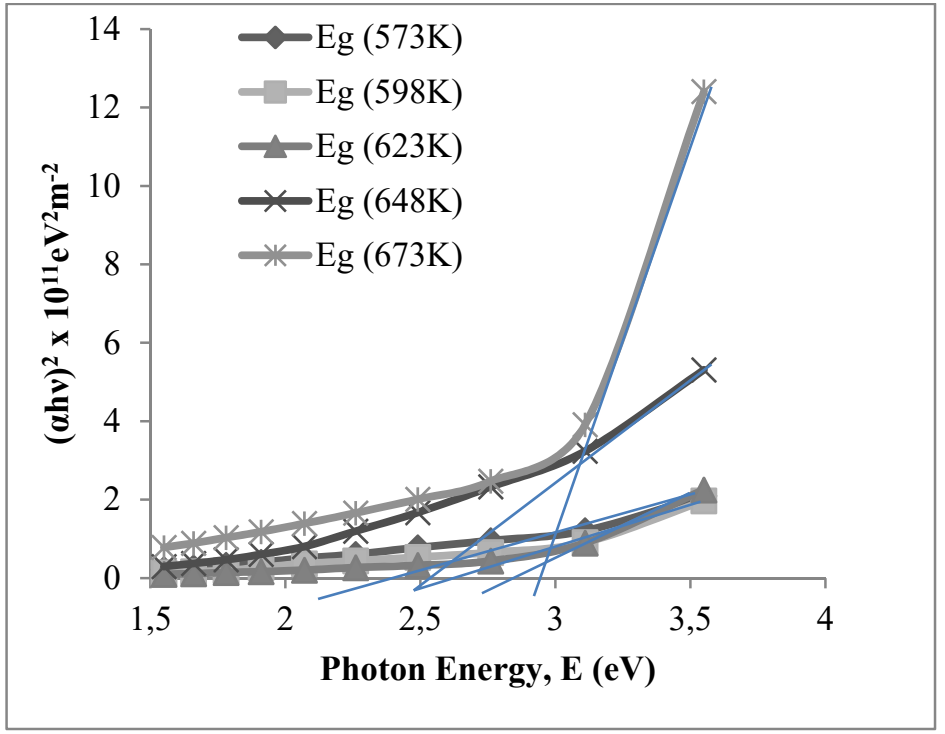

Fig. 3. Plot of $(\alpha h v)^{2}$ Versus Photon Energy for MgSe:Eu Films at Varying Substrate Temperatures.

The energy of band gaps of the films is within the range of $2.49 \mathrm{eV}$ to $2.95 \mathrm{eV}$ depending on the substrate temperature. The band gap energy is observed to increase slightly with temperature between $573 \mathrm{~K}$ and $623 \mathrm{~K}$, reduces at 648 and further increased at $673 \mathrm{~K}$. However, a clear observation shows that the band gaps of MgSe:Eu films are mainly 
dependent on thickness such that the obtained band gaps decreased with increasing thickness (band gap increases with thickness reduction).

Table 1a

Variation of Band Gap Energy with Substrate Temperature

\begin{tabular}{|c|c|}
\hline $\begin{array}{c}\text { Temperature } \\
(\mathbf{K})\end{array}$ & $\begin{array}{c}\text { Band Gap } \\
(\mathbf{e V})\end{array}$ \\
\hline 573 & 2.65 \\
\hline 598 & 2.75 \\
\hline 623 & 2.85 \\
\hline 648 & 2.49 \\
\hline 673 & 2.95 \\
\hline
\end{tabular}

Variation of Band Gap Energy with Thickness

\begin{tabular}{|c|c|}
\hline $\begin{array}{c}\text { Thickness } \\
\text { (nm) }\end{array}$ & $\begin{array}{c}\text { Band Gap } \\
(\mathbf{e V})\end{array}$ \\
\hline 2900 & 2.49 \\
\hline 2750 & 2.65 \\
\hline 2500 & 2.75 \\
\hline 2100 & 2.85 \\
\hline 200 & 2.95 \\
\hline
\end{tabular}

Table $1 \mathrm{~b}$ reveals that a reduction in the thickness of the $\mathrm{MgSe}: \mathrm{Eu}$ films caused a corresponding increment in band gap energy. Another notable observation is the fact that the $\mathrm{MgSe}: \mathrm{Eu}$ film thickness was astronomically reduced at $673 \mathrm{~K}$. At the occurrence of this fact, the films were repeatedly deposited at this temperature a couple of times with variation of thickness still in the reported range. A very similar report has been given by [2], citing [14] wherein the various authors concluded that at higher temperatures there is a reduction in the transfer of precursor to the substrate. This, [2] and [14] attributed to gas convection emanating from the chamber, hence pushing away the droplets from the substrate surface leading to the development of crystallites within the vapour. Thickness of MgSe:Eu films were determined by profilometry using a DekTak Veeco 150 Profilometer.

\section{STRUCTURAL CHARACTERIZATION OF MgSe:Eu FILMS \\ X-RAY DIFFRACTION (XRD) ANALYSIS}

The X-ray diffractogram of the Eu-doped MgSe films obtained at a deposition temperature of 623K, deposition time of 10 mins and 10\% dopant concentration is displayed in Figure 4.

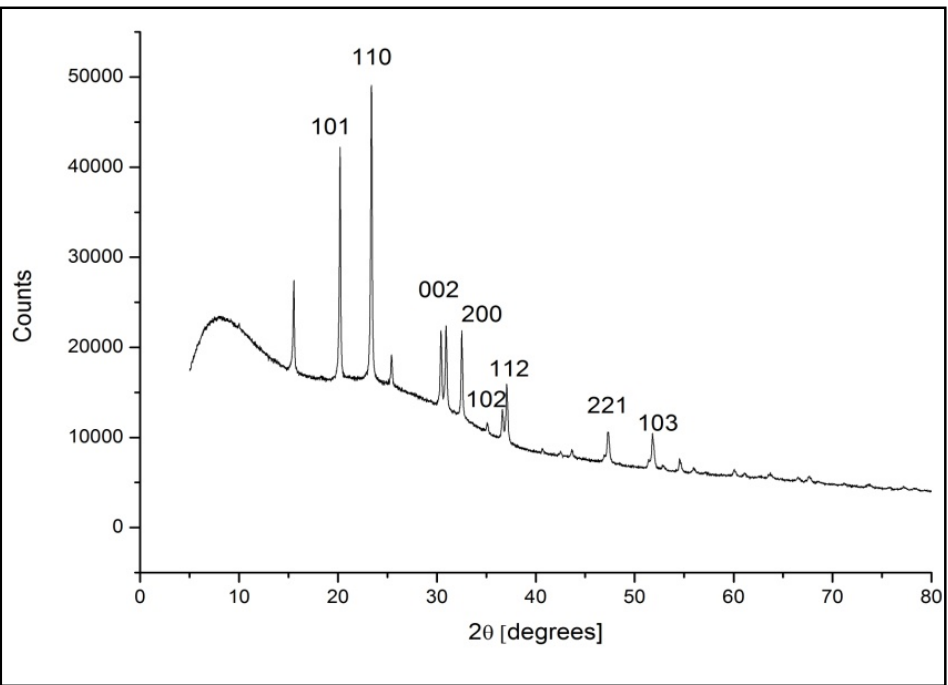

Fig. 4. XRD Diffractogram of MgSe:Eu Films at 623K and 10\% Dopant Concentration.

Figure 4 reveals multiple planes of reflection from the XRD pattern of the deposited $\mathrm{MgSe}: \mathrm{Eu}$ films. This indicates clearly that the films are polycrystalline. These diffraction patterns are indexed to the [101], [110], [002], [200], [102], [112], [221] and [103] planes having corresponding $2 \theta$ values: $20.37^{\circ}, 23.53^{\circ}, 30.67^{\circ}, 32.68^{\circ}, 36.77^{\circ}$, 
$37.21^{\circ}, 47.43^{\circ}$ and $51.97^{\circ}$ respectively. The indexed planes clearly suggests a hexagonal structure for the $\mathrm{MgSe}: \mathrm{Eu}$ films. The peak at $2 \theta$ equals $23.53^{\circ}$ recorded the highest intensity indicating the preferred growth angle which has been indexed to the [110] plane. The lattice constant for the [110] plane was estimated to be about 5.3427 $\AA$ which is lower than the reported standard value (5.462 $\AA$ ) published by NBS Monograph 25, section 5 (card no.: 53-61386) [15] for MgSe films.

In this research, optical studies reveal a blue-shift in band gap energy for the studied MgSe:Eu films while structural analysis shows the lattice constant $(5.3427 \AA)$ is red-shifted from the bulk $(5.462 \AA)$. It is to be emphasized that a reduction in the inter-atomic distance brings about a decrease in lattice constant. The implication of this is an increment in binding force between the valence electrons and parent atoms. Thus, as the valence electrons become more bound as a result of the decrease in inter-atomic spacing, more energy will be needed to free the valence electrons and move them into the conduction band to become free electrons. Thus a reduction of the lattice constant will result in an increase in the band gap energy. Thus, our structural and optical results are well correlated.

For an effective study of the structural details, parameters such as the grain size, inter-planar distance, strain, lattice constant, dislocation density and number of crystallites per unit area have been estimated and displayed in Table $2 b$.

The grain size, D, was estimated from the Debye-Scherer expression [2, 16-17]:

$$
\mathrm{D}=\frac{0.94 \lambda}{\beta \cos \theta}
$$

where $\lambda(1.540593 \AA)$ is the diffraction wavelength, $\beta$ is the Full-Width at Half-Maximum (FWHM) while $\theta$ is the Bragg's diffraction angle.

The grain/crystallite sizes of the MgSe:Eu films at the different planes presented were estimated to be 41.19nm, $46.15 \mathrm{~nm}, 47.79 \mathrm{~nm}, 48.56 \mathrm{~nm}, 52.97 \mathrm{~nm}, 54.81 \mathrm{~nm}, 61.76 \mathrm{~nm}$ and $70.92 \mathrm{~nm}$ respectively.

The inter-planar distance, $d$, was estimated from the expression [16]:

$$
d=\frac{\lambda}{2 \sin \theta}
$$

The strain, $\varepsilon$, was estimated from the expression [18]:

$$
\varepsilon=\frac{\beta \operatorname{Cos} \theta}{4}
$$

The dislocation density, $\delta$, was estimated from the mathematical expression [19-20]:

$$
\delta=\frac{1}{\mathrm{D}^{2}}
$$

where $\mathrm{D}$ is the grain size.

The lattice constant for the hexagonal phase of MgSe:Eu was estimated from the relation given by [21-22]:

$$
\frac{1}{\mathrm{~d}^{2}}=\frac{4}{3 \mathrm{a}^{2}}\left(h^{2}+\mathrm{hk}+k^{2}\right)+\frac{l^{2}}{\mathrm{c}^{2}}
$$

where $\mathrm{a}$; is lattice constant, $\mathrm{d}$ is the inter-planar spacing and hkl represents the miller indices.

The number of crystallites per unit area was calculated using the relation [23-24]:

$$
\mathrm{N}=\frac{\mathrm{t}}{\mathrm{D}^{3}}
$$

where $\mathrm{t}$, is the thickness of the $\mathrm{MgSe}: \mathrm{Eu}$ film and $\mathrm{D}$ is the crystallite size corresponding to each plane.

Diffraction Angles and FWHM Values for MgSe:Eu Films Deposited at 623K.

\begin{tabular}{|c|c|c|c|c|c|}
\hline $\mathbf{2 \theta}$ & $\boldsymbol{\theta}$ & $\operatorname{Cos} \boldsymbol{\theta}$ & $\begin{array}{c}\text { FWHM } \\
\boldsymbol{\beta}^{\mathbf{0}}\end{array}$ & $\begin{array}{c}\text { FWHM } \\
\text { (Radians) }\end{array}$ & $\boldsymbol{\beta C o s} \boldsymbol{\theta}$ \\
\hline 20.37 & 10.19 & 0.9842 & 0.1600 & 0.002793 & 0.002042 \\
\hline 23.53 & 11.77 & 0.9790 & 0.1600 & 0.002793 & 0.002734 \\
\hline 30.67 & 15.34 & 0.9644 & 0.1800 & 0.003142 & 0.003030 \\
\hline 32.68 & 16.34 & 0.9596 & 0.1400 & 0.002444 & 0.002345 \\
\hline 36.77 & 18.39 & 0.9490 & 0.1800 & 0.003142 & 0.002982 \\
\hline 37.21 & 18.61 & 0.9477 & 0.1600 & 0.002793 & 0.002647 \\
\hline 47.43 & 23.72 & 0.9156 & 0.2200 & 0.003840 & 0.003516 \\
\hline 51.97 & 25.99 & 0.8989 & 0.2000 & 0.003491 & 0.003138 \\
\hline
\end{tabular}


Lattice Parameters for MgSe:Eu Films Deposited at 623K.

Table $2 b$

\begin{tabular}{|c|c|c|c|c|c|c|}
\hline $\begin{array}{c}\mathbf{D} \\
(\mathbf{n m})\end{array}$ & $\begin{array}{c}\mathbf{d} \\
(\AA)\end{array}$ & $\begin{array}{c}\mathbf{\varepsilon} \\
\left(\mathbf{x} \mathbf{1 0}^{-4}\right)\end{array}$ & $\begin{array}{c}\mathbf{\delta} \\
\mathbf{( \mathbf { x } \mathbf { 1 0 } ^ { \mathbf { 1 4 } }} \\
\left.\mathbf{l i n e s} / \mathbf{m}^{\mathbf{2}}\right)\end{array}$ & $\begin{array}{c}\mathbf{a} \\
(\mathbf{\AA})\end{array}$ & $\begin{array}{c}\mathbf{N} \\
(\mathbf{x ~ 1 0} \mathbf{1 5})\end{array}$ & $\mathbf{h k \mathbf { ~ }}$ \\
\hline 70.92 & 4.3562 & 5.1050 & 1.9882 & 6.1606 & 7.71 & 101 \\
\hline 52.97 & 3.7779 & 6.8350 & 3.5640 & 5.3427 & 18.50 & 110 \\
\hline 47.79 & 2.9127 & 7.5750 & 4.3785 & 5.8254 & 25.20 & 002 \\
\hline 61.76 & 2.7380 & 5.8625 & 2.6217 & 5.4760 & 11.67 & 200 \\
\hline 48.56 & 2.4423 & 7.4550 & 4.2408 & 5.4612 & 24.02 & 102 \\
\hline 54.81 & 2.4144 & 6.6175 & 3.3287 & 5.9141 & 16.70 & 112 \\
\hline 41.19 & 1.9153 & 8.7900 & 5.8941 & 5.7459 & 39.35 & 221 \\
\hline 46.15 & 1.7581 & 7.8450 & 4.6952 & 5.5596 & 27.98 & 103 \\
\hline
\end{tabular}

The diffractogram of Eu-doped MgSe films obtained at $623 \mathrm{~K}, 10$ mins deposition time and $40 \%$ dopant concentration is displayed in Figure 5.

The reflections are indexed to [101], [110], [002] and [200] planes which clearly indicates a hexagonal structure for the film. The reflection angles corresponding to the indexed planes have $2 \theta$ values at $20.26^{\circ}, 23.43^{\circ}, 30.46^{\circ}$ and $32.57^{\circ}$ respectively. The lattice constant of the preferred growth plane was estimated to be about $5.3652 \AA$. The

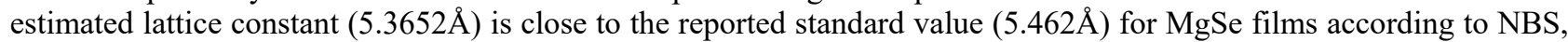
card no.: 53-61386 [15].

By comparison of Figures 4 and 5, it is observed that the number of prominent peaks decreased substantially when the dopant concentration was increased to $40 \%$. This implies that the material losses its crystallinity at increased dopant concentration, thereby distorting the crystal structure of the material.

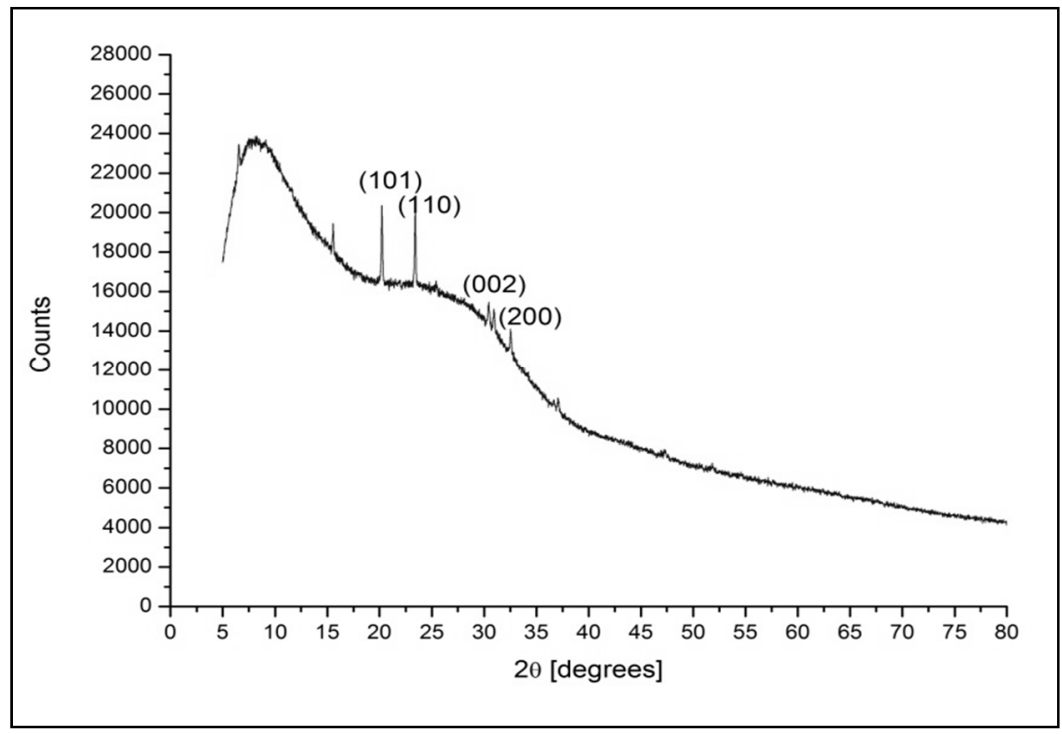

Fig. 5. XRD Diffractogram of MgSe:Eu Films at $623 \mathrm{~K}$ and 40\% Dopant Concentration.

Diffraction Angles and FWHM Values for MgSe:Eu Films Deposited at 623K, 40\%.

Table 3a

\begin{tabular}{|c|c|c|c|c|c|}
\hline $\mathbf{2 \theta}$ & $\boldsymbol{\theta}$ & $\operatorname{Cos} \boldsymbol{\theta}$ & $\begin{array}{c}\text { FWHM } \\
\boldsymbol{\beta}^{\mathbf{o}}\end{array}$ & $\begin{array}{c}\text { FWHM } \\
\text { (Radians) }\end{array}$ & $\boldsymbol{\beta C o s} \boldsymbol{0}$ \\
\hline 20.26 & 10.13 & 0.9844 & 0.1200 & 0.002094 & 0.002061 \\
\hline 23.43 & 11.72 & 0.9792 & 0.1200 & 0.002094 & 0.002051 \\
\hline 30.46 & 15.23 & 0.9649 & 0.1600 & 0.002793 & 0.002695 \\
\hline 32.57 & 16.29 & 0.9599 & 0.1400 & 0.002444 & 0.002346 \\
\hline
\end{tabular}


Lattice Parameters for MgSe:Eu Films Deposited at 623K, 40\%.

\begin{tabular}{|c|c|c|c|c|c|c|}
\hline$\underset{(\mathbf{n m})}{\mathrm{D}}$ & $\begin{array}{c}\text { d } \\
(\AA)\end{array}$ & $\begin{array}{c}\varepsilon \\
\left(\mathbf{x} 10^{-4}\right)\end{array}$ & $\begin{array}{c}\delta \\
\left(\begin{array}{c}\mathbf{1} 10^{14} \text { lines } / \mathrm{m}^{2}\end{array}\right)\end{array}$ & $\begin{array}{c}\text { a } \\
(\AA)\end{array}$ & $\begin{array}{c}\mathrm{N} \\
\left({\mathrm{x} 10^{15}}^{15}\right)\end{array}$ & hkl \\
\hline 70.26 & 4.3796 & 5.1525 & 2.0257 & 6.1937 & 8.650 & 101 \\
\hline 70.61 & 3.7938 & 5.1275 & 2.0057 & 5.3652 & 8.522 & 110 \\
\hline 53.73 & 2.9323 & 6.7375 & 3.4639 & 5.8646 & 19.341 & 002 \\
\hline 61.73 & 2.7500 & 5.8650 & 2.6243 & 5.5000 & 12.754 & 200 \\
\hline
\end{tabular}

SCANNING ELECTRON MICROSCOPY (SEM) STUDIES

The surface morphology of the MgSe:Eu films were studied at different conditions of growth and presented in Figures 6 (a-d).

From SEM images, cracks are evident all over the surface of the grown films (Figures 6(a-d) indicating that the films are highly strained). Such strains lead to defects within the crystal structure of the material. This is evident in the optical and XRD analysis.

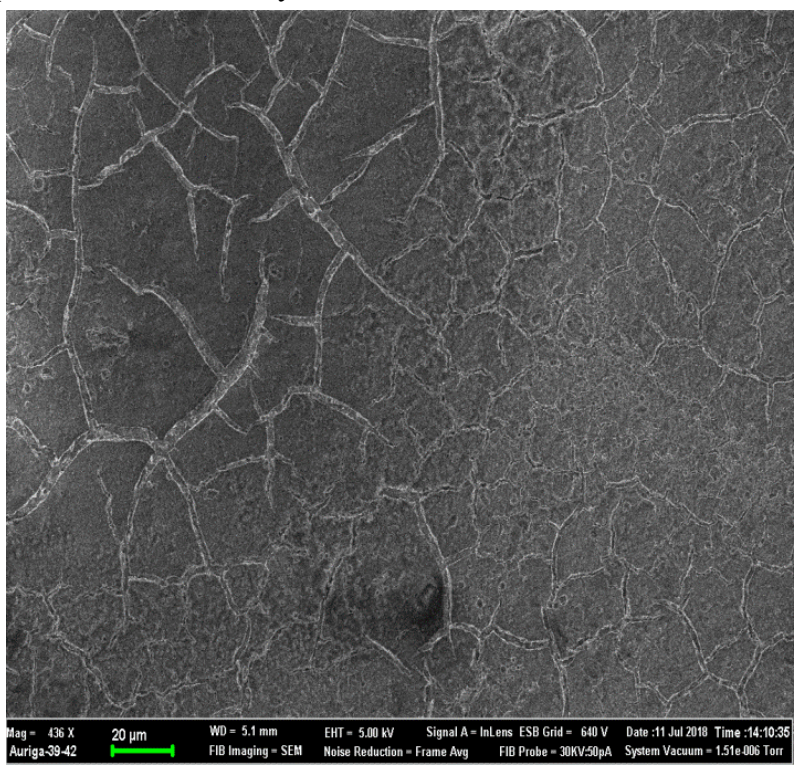

Fig. 6a. SEM Image of MgSe:Eu Films at 573K, 10mins and $10 \%$ Dopant Concentration.

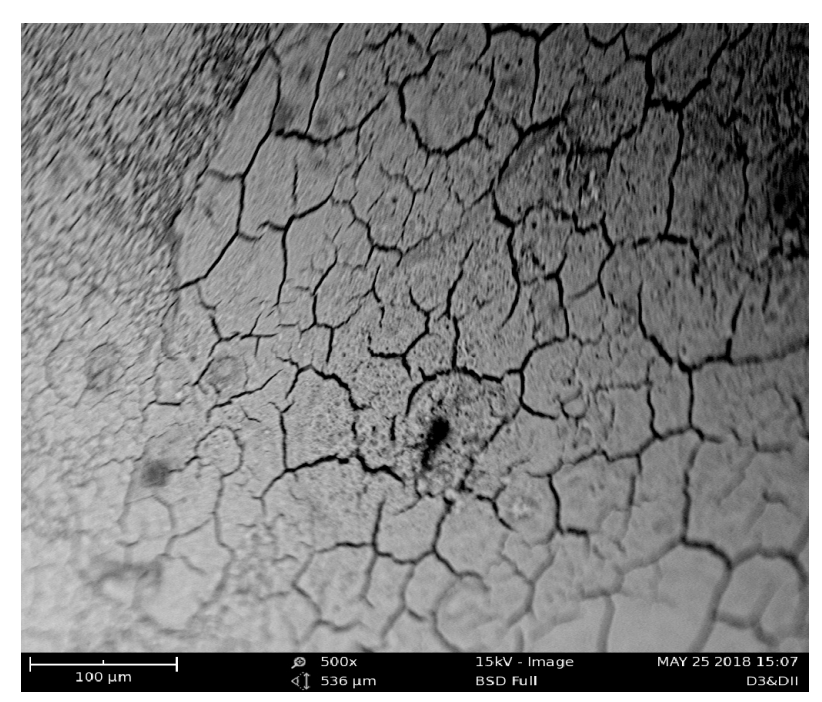

Fig. 6c. SEM Image of MgSe:Eu Film Obtained at 623K, $10 \mathrm{mins}, 10 \%$ Dopant Concentration at a Resolution of 500x.

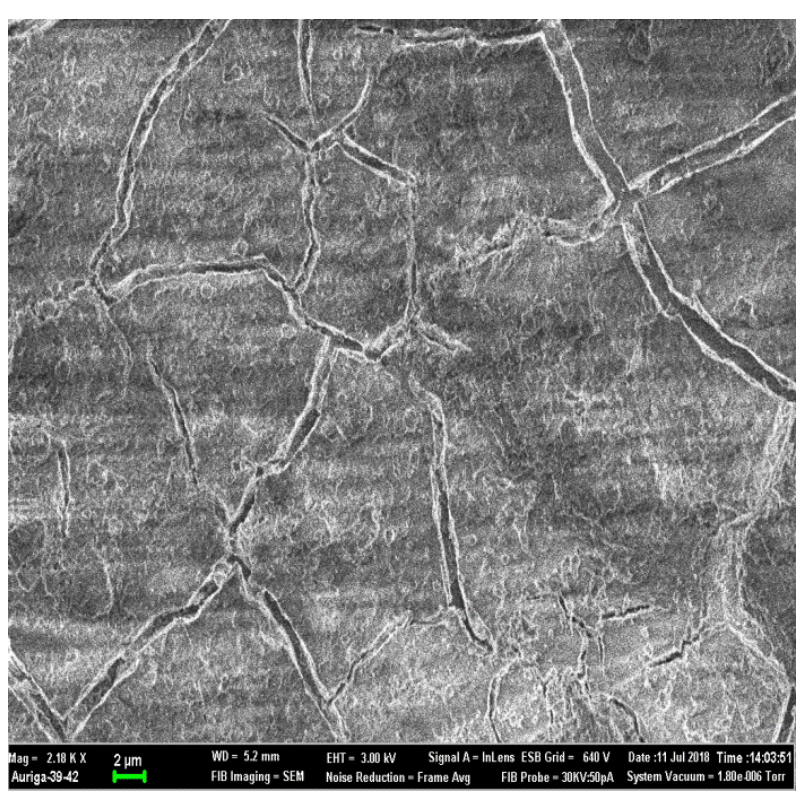

Fig. 6b. SEM Image of MgSe:Eu Films at 623K, 10mins and $40 \%$ Dopant Concentration.

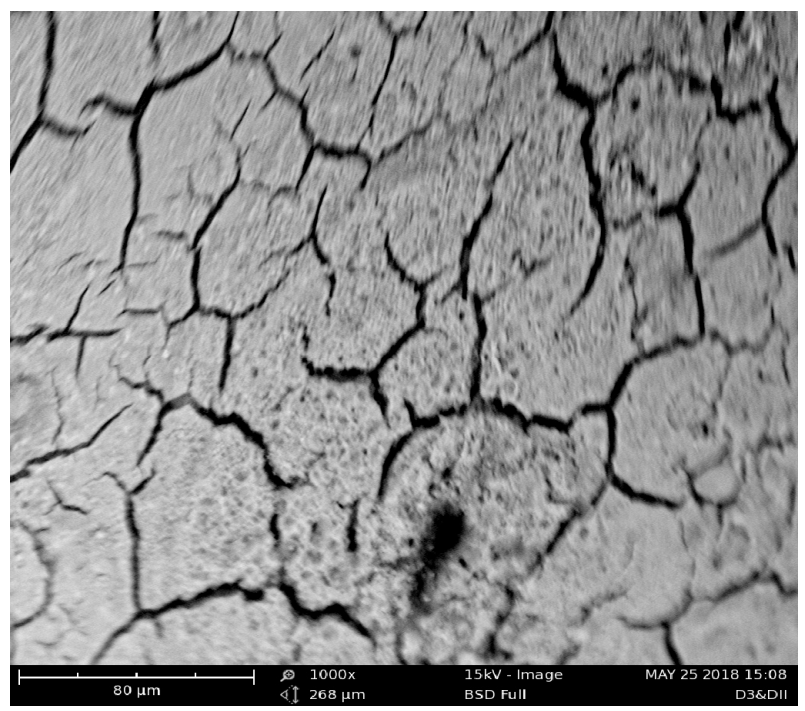

Fig. 6d. SEM Image of MgSe:Eu Film Obtained at 623K, 10 mins, $10 \%$ Dopant Concentration at a Resolution of 1000x. 


\section{ELEMENTAL COMPOSITION}

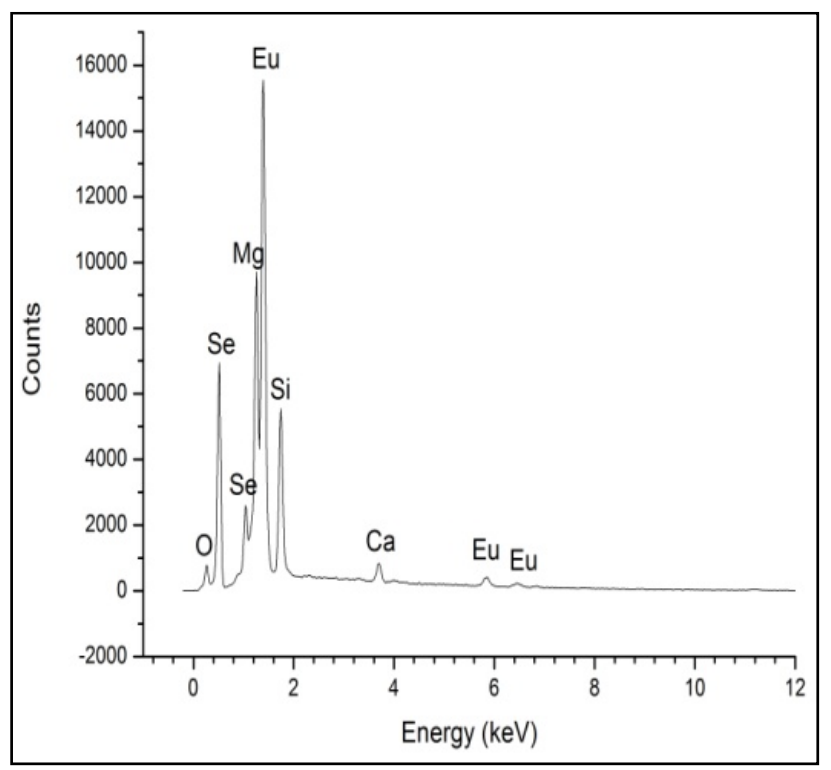

Fig. 7. EDX Spectrum of MgSe:Eu Films at $10 \% \mathrm{Eu}$ Concentration and Growth Temperature of 573K.

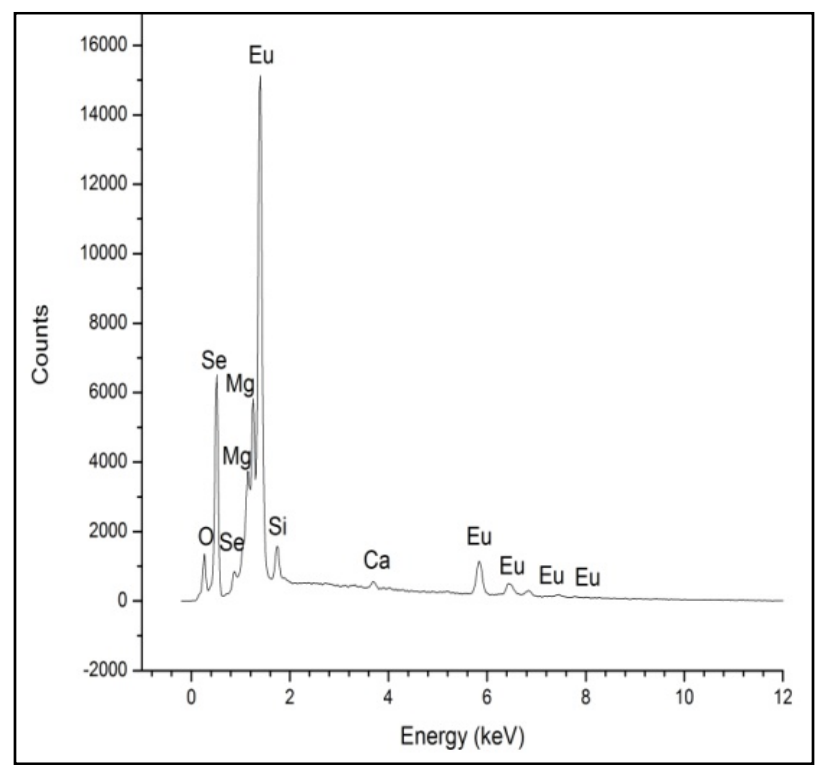

Fig. 8. EDX Spectrum of MgSe:Eu Films at $40 \% \mathrm{Eu}$ Concentration and Growth Temperature of $623 \mathrm{~K}$.

To confirm the growth of MgSe:Eu films, energy dispersive analysis X-ray (EDX) spectroscopy was employed to ascertain the composition of the films. Figures 7 and 8 show the EDX spectrum of the MgSe:Eu films obtained at 10\% and $40 \% \mathrm{Eu}$ concentrations at growth temperatures of $573 \mathrm{~K}$ and $623 \mathrm{~K}$. The presence of $\mathrm{Mg}$, Se and Eu is obvious from the EDX spectrum confirming the formation of $\mathrm{MgSe}: \mathrm{Eu}$ films. The presence of silicon (Si) and calcium (Ca) may have come from the glass substrate while the peak corresponding to oxygen $(\mathrm{O})$ may be due to atmospheric exposure.

\section{CONCLUSION}

Thin films of MgSe:Eu with varying thicknesses obtained at varying substrate temperatures and dopant concentrations were obtained via electrostatic spray pyrolysis. The obtained band gap energies were discovered to be dependent on the film thickness. Strong blue-shift in band gap energy was observed for the MgSe:Eu films. Optical studies reveal the films will prove useful in creating optoelectronic devices and will also be valuable for coating materials that need to remain transparent. The XRD analysis conducted indicates hexagonal structure for the $\mathrm{MgSe}: \mathrm{Eu}$ films while SEM analysis indicates the MgSe:Eu films are highly strained.

\section{ACKNOWLEDGEMENT}

The authors wish to appreciate the management and technicians at NAMIROCH laboratory, Abuja for assisting in conducting our research.

D.M. Jeroh (1) https://orcid.org/0000-0002-1622-0337

\section{ORCID IDs}

A.J. Ekpunobi (iD https://orcid.org/0000-0002-5111-7298

D.N. Okoli (i) https://orcid.org/0000-0002-4196-8902

\section{REFERENCES}

[1]. Y.S. Sakhare, N.R. Thakare and A.U. Ubale, St. Petersburg Polytech. Uni. J. Phys. Math. 2, 7-26 (2016).

[2]. S.J. Gnanamuthu, S.J. Jeyakumar, A.R. Balu, K. Usharani and V.S. Nagarethinam, Int. J. Thin Fil. Sci. Tech. 2, 121-123 (2015).

[3]. Y.S. Sakhare, N.R. Thakare and A.U. Ubale, Arch. Phys. Res. 6, 12-20 (2015).

[4]. A.U. Ubale, Y.S. Sakhare, Vacuum. 99, 124 (2014).

[5]. A.U. Ubale, Y.S. Sakhare, Mater. Sci. Semicond. Process. 16, 1769 (2013).

[6]. A.U. Ubale, Y.S. Sakhare, S.G.Ibrahim and M.R. Belkhedkar, Solid State Sci. 23, 96-108 (2013).

[7]. A.U. Ubale, Y.S. Sakhare, Ind. J. Phys. 87, 1183-1188 (2013).

[8]. H.M. Wang, J.H. Chang, T. Hanada, K. Arai and T. Yao, J. Cryst. Growth. 208, 253-258 (2000).

[9]. P.X. Feng, J.D. Riley, R.C.G. Leckey and L. Ley, J. Phys.: Appl. Phys. D. 34, 1293-1300 (2001).

[10]. F. Jiang, Q. Liao, G. Fan, C. Xiong, X. Peng, C. Pan and N. Liu, J. Cryst. Growth. 183, 289-293 (1998).

[11]. P. Prete, N. Lovergine, L. Tapfer, C.Z. Fregonara and A.M. Mancini, J. Cryst. Growth. 214-215, 119-124 (2000).

[12]. M.D. Jeroh, A.J. Ekpunobi, D.N. Okoli, J. Nano- Electron. Phys. 10, 03006-1 (2018).

[13]. D.H. Hwang, J.H. Ahn, K.N. Hui, K.S. Hui and Y.G. Son, Nanoscale Res. Letts. 7, 26 (2012).

[14]. M Suganya, A.R. Balu and K. Usharani, Mater Sci Poland. 3, 448-456 (2014). 
[15]. Standard X-ray Diffraction Powder Patterns. National Bureau of Standards Monograph, 25 - Section 5, (US Department of Commerce, Washington, 1967).

[16]. N.J.S. Kissinger, M. Jayachandran, K. Perumal and C.S. Raja, Bull. Mater. Sci. 3, 547-551 (2007).

[17]. R.S. Meshram, R.M. Thombre, Int. J. Adv. Sci. Eng. Technol. 1, 161-170 (2015.).

[18]. S. Muthumari, G. Devi, P. Revathi and R. Vijayalakshmi, J. Appl. Sci. 12, 1722-1725 (2012). doi: 10.3923/jas.2012.1722.1725

[19]. J. Pla, M. Tamasi, R. Rizzolt, M. Losurdo, E. Centurioni, C. Summonte and F. Rubinelli, Thin Solid Films. 425, 185-192 (2003).

[20]. Y.Z. Dawood, M.H. Hassoni and M.S. Mohamad, Int. J. Pure. Appl. Phys. 2, 1-7 (2014).

[21]. N.J.S. Kissinger, J. Suthagar, B.S. Kumar, T. Balasubramaniram and K. Perumal, Acta. Phys. Pol. A. 118, 623-628 (2010).

[22]. V.D. Mote, J.S. Dargad and B.N. Dole, Nanosci. Nanoeng. 1, 116-122 (2013). doi: 10.13189/nn.2013.010204

[23]. Z.R. Khan, M. Zulfequar and M.S. Khan, Mater. Sci. Eng. B. 174, P.145-149 (2010).

[24]. S.A. Aly, A.A. Akl and H. Howari, Acta. Phys. Pol. A. 128, 414-418 (2015). doi: 10.12693/APhysPolA.128.414 